Vuk Miletić

High School of Academic Studies "Dositej", Belgrade
SCIENTIFIC REVIEW ARTICLE doi:10.5937/ekonomika1803067M

Received: August, 10, 2018 Accepted: September, 07, 2018

\title{
BUSINESS MODEL ADJUSTMENT - A CONDITION OF AN ORGANIZATION'S SUSTAINABILITY ON THE MARKET
}

\begin{abstract}
Utilizing the analytical descriptive method, this paper examines the business model as an especially useful concept, considering the fact that organization managers are often unable to explain the complexities of business regulations and elements in an understandable way. A contemporary approach views the business model as a tool that assists the understanding, visualization and communication of the basic nature of conducting business to parties of interest and influence. The purpose of this article is to clearly describe the spectrum of business model concepts and to give a clear overview of its essential components. What is more, the paper emphasizes the role and importance of inovating the business model as a determinant of a contemporary organization's sustainable competitive advantage. It is believed that business models are able to change the fundamental nature of business regarding the organization's value creation and to set new competition standards in a given industry.
\end{abstract}

Key words: business model, organization, innovation, sustainability.

JEL Classification: M21, O31

\section{ПРИЛАГОЪАВАЊЕ ПОСЛОВНОГ МОДЕЛА - УСЛОВ ОДРЖИВОСТИ ОРГАНИЗАЦИЈЕ НА ТРЖИШТУ}

\begin{abstract}
Апстракт
У раду се аналитичко дескриптивним путем разматра пословни модел као посебно користан концепт, с обзиром да менацери организација често нису у стағу да објасне комплексност пословних одредница и елемената на разумљив начин. Савремени приступ проматра пословни модел као алат који помаже разумевању, визуализачији и комуницирању суштине пословања интересно -утицајним групама. Сврха је овог чланка да јасно опише спектар кониепта пословног модела и пружи јасан приказ юегових градивних елемената. Такође, нагламена је улога и важност иновирања пословног модела као детерминанте одрживе конкурентске предности сувремене организачије. Сматра се да пословни модели могу променити суштину бизниса у смислу стварања вредности од стране организације и поставити нове стандарде такмичења у појединој индустрији.
\end{abstract}

Кључне речи: пословни модел, организащија, иновације, одрживост.

\footnotetext{
${ }^{1}$ vuk.miletic88@gmail.com
} 


\section{Introduction}

The process of value creation by an organization, i.e. the way in which it generates sustainable growth is in the center of the business model. In the business world, the profitability of certain industries significantly differs, so the pharmaceutical and the airline industries on average differ by tens of percent when it comes to the rate of investment return. There are industrial factors that enable organizations in certain industries to reach a higher level of profitability. However, there is an even more significant profitability difference among companies in the same industry that is created by the business models that they use. Relevant research my IBM Institute for Business Value from 2016 shows that 8 out of 10 companies work on innovating their business system and $97 \%$ of surveyed companies work on modifying the existing business model. This poses the questions of what the cause of such intense research and perfecting of the business system is. The fact is that, these days, the current business systems of creating new value and of placing that value on the market are faced with serious challenges. They include strong business globalization, economic crisis in industrially developed countries, a limiting operation of the open market in developing countries, the advent of new companies coming from growing economies from the east that offer competitive prices, the creation of new technologies founded on information technologies where a special challenge is the influence of the internet on business models, and so on. To sustain their business and to be able to survive on such a complex market, the leading global and domestic companies direct their managerial activities towards creating an innovative culture that should encourage innovation in the business model, product, and working operations region.

Basically, a quality business model should answer the question of where an organization's profit is coming from. If the management's answer to this question is not precise or if the inflow of funds coming from realized activities does not cover the expenses and does not leave a satisfactory level of profit, it is clear that the organization does not have a good business model.

\section{Business model}

The business model of an organization is a system of transforming the incoming resources via business activities into outputs and outcomes that are supposed to realize its strategic goals and to create value during a designated time period. The outcomes of a business model are identified as incomes and they are tracked through performance increase, employee morale and the organization's reputation on the market. Ultimately, along with leadership, a business model is one of the factors that make certain organizations more profitable than others [Afuah, 2004].

A business model is also identified as an organization's plan for combating competition, using the available resources, structuring relationships, handling consumers and creating value to enable the sustainability of conducting business. This goal creates the demand that contemporary organizations be efficient, flexible, innovative and careful for the purpose of achieving a sustainable competitive advantage [Linde, Herr, Rehklau, 2006]. In this sense, the business model represents a rational explanation of 
how an organization creates, delivers and valorizes the economic, social, cultural, or any other form of value to the consumers on the market. A business model depends on the resources that are under an organization's control and the competence it possesses. Different business models are used to describe and classify businesses, especially in the entrepreneurial sphere, but they are also used by managers in companies to explore the possibilities for future growth, which means they can functions as "recipes" for creative managers [Baden-Fuller, Charles; Morgan, 2010]. A further expansion of this logic points to the significance of a continual need to develop the business model as a mechanism that enables leaders to build successful and sustainable organizations [George, Bock, 2012].

From a theoretical viewpoint, in a changeable environment there comes a question of whether there exists and if so, what the difference is between a business model, business plan, and an organization's strategy. Researchers in this area mostly agree that they are all different concepts. Thereby, the difference is as follows:

- a strategy is, first of all, focused on the product-market relation, that is, on building a distinction from the competition;

- a business model is a wider term that, aside from the product-market relation, involves the process of value creation;

- a business model is more focused on fulfilling consumer demands;

- $\quad$ the newly created value should represent value for all parties of interest, and it should include sustainable business conduct.

From the abovementioned stems the conclusion that the concept of a business model is very similar to the concept of strategy. The key difference lies in the fact that two organizations can have the same focus group and a similar strategy, but they can implement quite different business models. A business model exists when an organization knows its market, its consumers, their values, and how it creates new value for them [Drucker, 1994, p. 99].

What is more, the question regarding the difference between a business model and a business plan is also posed. A business model is on a higher level of abstraction and it refers to the rational explanation of business conduct, whereas a business plan gives details or plans of conducting business. A business model is the foundation on which a business plan is built, and the plan identifies the necessary personnel, resources, marketing strategy, and the financial aspect for a predetermined period of time. Simply put, a business model precedes the creation of a business plan.

To determine what a business model is presents quite a challenge. There is no standard business model, even though it should entail all activities that describe how an organization should behave on the market. There are numerous tools that can help an organization's management with the development of an adequate business model. One of those tools is the "Business model Canvas" (picture 1) that enables a better understanding of the essence of the business model in general, considering it is one of the more often used models in practice [www.pokreni.se/business-canvas-model/]. It is a dynamic and simple managerial tool that all organizations can implement, and it enables the designing, development, description, improvement, and testing of a new business model. Subject business model is a tool of strategic management in the shape of a visual diagram [Cowan, 2013] that includes:

- consumer focus group, 
- a promise of the value to be delivered to consumers,

- expense structure,

- $\quad$ value delivery system,

- customer relations

- income

- main resources (basic abilities),

- $\quad$ key activities (value configuration), and

- $\quad$ key partners.

\begin{tabular}{|c|c|c|c|c|}
\hline \multirow{2}{*}{$\begin{array}{c}\text { Basic } \\
\text { abilities }\end{array}$} & $\begin{array}{l}\text { PARTNER } \\
\text { NETWORK }\end{array}$ & OFFER & $\begin{array}{l}\text { CUSTOMER } \\
\text { RELATIONS }\end{array}$ & CUSTOMERS \\
\hline & $\begin{array}{l}\text { Describt the partner } \\
\text { network and the }\end{array}$ & Suggested & \multirow{2}{*}{$\begin{array}{l}\text { Explain the nature } \\
\text { of the relations with } \\
\text { customers }\end{array}$} & $\begin{array}{l}\text { BASIC } \\
\text { ABILITIES }\end{array}$ \\
\hline \multirow{3}{*}{$\begin{array}{l}\text { Define the abilities } \\
\text { necessary to realize } \\
\text { the business model }\end{array}$} & $\begin{array}{l}\text { arrangement with } \\
\text { other companies }\end{array}$ & \multirow{3}{*}{\begin{tabular}{|l|} 
A general \\
review of \\
products and \\
services \\
\end{tabular}} & & \multirow{3}{*}{$\begin{array}{l}\text { Define the abilities } \\
\text { necessary to realize } \\
\text { the business model }\end{array}$} \\
\hline & $\begin{array}{c}\text { VALUE } \\
\text { CONFIGURATION }\end{array}$ & & \multirow[b]{2}{*}{\begin{tabular}{|l|}
\multicolumn{1}{|c|}{$\begin{array}{l}\text { Distribution } \\
\text { channels }\end{array}$} \\
Describe the \\
channels via which \\
you contact and \\
communicate with \\
customers \\
\end{tabular}} & \\
\hline & $\begin{array}{l}\text { Describe the } \\
\text { arrangement of activities } \\
\text { and resources }\end{array}$ & & & \\
\hline $\begin{array}{l}\text { Summearize the } \\
\text { monetary results of } \\
\text { the application of } \\
\text { the business model }\end{array}$ & $\begin{array}{l}\text { EXPENSE } \\
\text { STRUCTURE }\end{array}$ & FINANCES & INCOMl & $\begin{array}{l}\text { Describe the } \\
\text { money - making } \\
\text { processes }\end{array}$ \\
\hline
\end{tabular}

Picture 1. Business model structure

At the beginning of the model are the clients to which the organization delivers value. Of course, the key segment of the stated model is the suggestion of the value to be delivered to customers and it signifies the organization's ability to consider customer needs and to deliver the promised value in a realistic ambiance at affordable prices. This means that key values which are offered should be developed for each group of clients, including cost assessment and the expected income. The next is the system or network that represents the points of contact with the customers via which key value is delivered. This model stresses that an organization should build target consumer and key associate relations of the highest possible quality, which can bring a specific advantage to the model, whether it is resources or activities.

\section{Creating an innovative business model}

In economic theory, the market is seen as a mechanism that solves all problems, whereas in practice business models were created to deal with market problems. To serve their purpose, business models have developed over time and they have become more and more sophisticated. All organizations, implicitly or explicitly, develop a business model that in essence implies management assumptions as to what consumers want, how they want it and how a company can be organized to satisfy the researched consumer needs, 
and to make profit while doing so [Teece, 2010]. Thus a good business plan is extremely important for any organization. The organization's management is in charge of designing a business model. The logic of shaping a business model is seen by the managers/leaders as the result of creating new or reshaping the existing organizational structure in order to take the opportunity of establishing the organization on the target market [Zott, Amit, Massa, 2010]. Research conducted in the USA has shown that business models are truly indispensable for the sustainability of any company's business.

The process of building and modifying a business model is seen as an innovation of a business model and it represents a segment of an organization's business strategy [Geissdoerfer, Martin; Savaget, Paulo; Evans, Steve, 2017]. A thorough strategy, strateic resources, partner networks, and customer relations are components of every business mod-el, and by changing it, their structure is changed. Inovating a business model represents a change in the activity of creating, implementing and validating a new model. Chesbro-ugh (2007) believes that "a better business model is more important to an organization and its management than a better idea or technology". As an example for a better understanding of what a change of the business model can represent, the change that the company Volvo realized is often cited [Business Model, 2013]. An analysis of Volvo's existing business model (picture 2) has shown that it has practically not changed since the founding of the company and everything pointed to the necessity of innovating it.

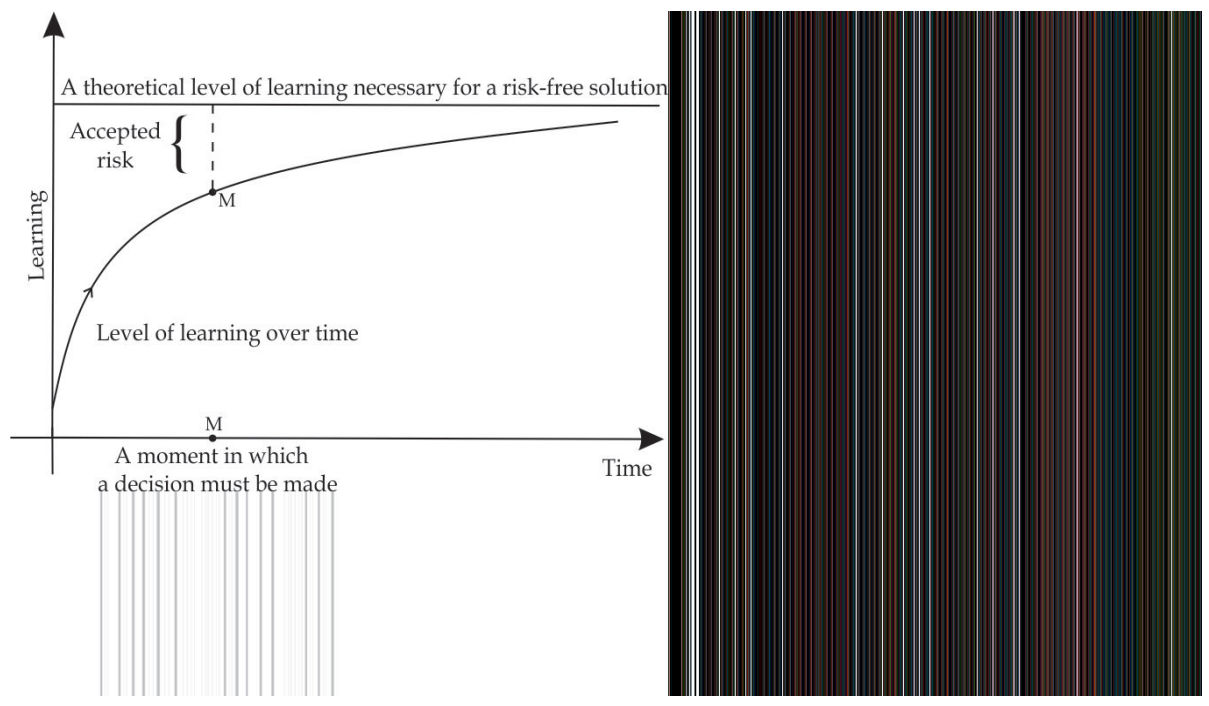

Picture 2. The change of Volvo's business model

The Volvo corporation delivered vehicles to local dealers who sold them and maintained customer communication. By the advent of the Internet, the preconditions for a business innovation were created, and that innovation was: All cars that were sold were connected with the corporation via the internet with the added option of car control and providing technical advice. This way, new services were created, such as: remotely turning on the heating in cars; tracking a stolen vehicle; door lock control; viewing the dashboard; insight into the condition of the engine; service time, etc. From 
the abovementioned, it is evident that an applied innovation into the business model adds significant value to consumers.

The aforementioned business model canvas helps organizations to implement structural and strategic analyses of existing affairs or analyses to create new sources for growth and development. Graphically showing a business model undoubtedly helps the strategic management to clearly and understandably represent business logic and the process of value creation to all interested stakeholders [Fensel, 2001]. So far, there are three kinds of innovation that have been recognized in the practice of innovating a business model, and they are found in the areas of [Linde, Herr, Rehklau, 2006]:

- valorizing delivered value,

- an organization's functioning (the inner chain of industry), and

- the industry of redefining the existing, or creating new industry.

In fact, the kind of contemporary business models mostly depends on the way technology is used. For example, entrepreneurs have created new models online that wholly depend on existing technology. By the use of technology in a competitive environment, companies are able to reach great numbers of consumers to whom they can offer expected value with minimal expense. With the growth of outsourcing and globalization, the reality is that business models must greatly respect strategic sources, complex supply chains, cooperation activities and relational contract structure [University of Tennessee, 2014]. Any change in the suggested business model structure entails the identification of product or service quality, where special attention should be paid to the target consumer group to which the organization is referring and to the suggested value to be delivered. The suggested value [Baden-Fuller, Mangematin, 2013, p. 419420] should answer the following questions: What kind of value is delivered to the consumers? Which products/services does the organization offer and to which segment of the market? Which consumer issue is being dealt with? Which consumer demand is being met? The attributes of suggested value can refer to: novelty, performance, adjusting to consumer needs, design, brand/status, price, cost reduction, risk reduction [Lambert, 2006], etc. From this stems the fact that the decision regarding the market segment and the quality of the product/service is made in the business model identification phase. A wrong assessment of consumers and expenses is the most common mistake that should be avoided in the suggested business model structure.

Considering the fact that the business model precedes the business plan, i.e. documenting certain managing systems, it is especially important to articulate and understand the concept of business model prior to any sort of documenting. Namely, experience shows that documenting management systems does not reflect a realistic business model, but it is tailored to meet the demands of the prescribed standards. This should be particularly emphasized, since an individual organization can have more than one business model for managing its business portfolio. In any case, new business models can change the essence of doing business and set new competition standards in a given industry [Zott, Amit, and Massa, 2011; Cliffe and McGrath, 2011]. Multiple iteration (renovation) and rotation of an initially conceived business model results in a sustainable business model that needs to be further elaborated into a business plan [Blank, 2005]. 


\section{What is and what is not important for an organization in the process of value creation?}

As numerous authors point out, an organization's management emphasizes added value creation when identifying a business model [Afuah, 2004; Tecce, 2010; Casadesus - Masanell, Ricart, 2009; Zott, Amit, 2010]. It is about the value that an organization creates and distributes, as well as the profitability that stems from the creation and distribution of value to customers. Incidentally, practice shows that there is no defined business model in explicit form, which is why the management is forced to create such a business concept that could answer the question of what is and is not important to an organization, i.e. what the risk of realizing set goals and value chain is [Baden-Fuller, Mangematin, 2013]. In that sense, an organization's leadership has a special role in creating an innovative business model.

Above all, creating and delivering added value to customers is necessary for maintaining an organization's business sustainability on the target market. The delivery of expected value depends on innovativeness in creating a business model with an adequate integration of different management systems [Božilović, Miletić, 2014, p. 36]. Organizations realize business sustainability on a certain market by realizing all necessary activities through a suitable process. In business practice, numerous domestic organizations have adopted or are in the process of adopting an official management system that should enable a profitable creation of new value to a business model. It is unimaginable for an organization to function without being based on multiple management systems. It is essential to completely understand the business of an organization to enable the creation of added value by the process of management system assessment. An innovative business model [Dwight, 2015] as a clear concept for this purpose gives the necessary information regarding business goals, strategies, politics, and business plans.

The market ultimately verifies whether an organization with an altered business model has created new value. The assessment of management system in the function of creating added value is created by the assessment of individual processes that are essential to the assessed system, the most important being the system of product quality. For each identified process, the management of an organization determines the inbound and outbound outcomes, including selected constants, performance indicators, success evaluation methods and the improvement of the processes themselves, etc. The inbound elements in the process require market analysis, information on customer satisfaction, prognoses regarding the direction of applied technology development [Miletić, et. al, 2017 , p. 41] etc. For the most part, the processes being evaluated are defined, even though there are some undefined ones. The undefined segment of a process can be said to be a potential risk for the attainment of goals in the process, since this part of the process is not completely mastered. An example of a process's indeterminacy in an organization is the phenomenon of the so-called technological waste that is difficult to remove and which appears as a consequence of being insufficiently familiar with the process.

The correlation between a directed risk and process indeterminacy points to the conclusion that the main task of the management is to reduce the vagueness via process. The correlation between indeterminacy and learning about a process while making 
executive decisions (picture 3) suggests that the way to risk reduction lies in increasing the knowledge about a managed process.

In order to remove any non-compliance when creating added value, improvements in the management system are needed. This means that an adequate assessment of a system can help create added value. In this manner, creating added value in organizations at a lower level of management maturity is directed at a complete understanding and application of the principles and demands of the right assessment standard. At higher levels of management maturity, attention should be paid to identifying the risks of realizing set goals.

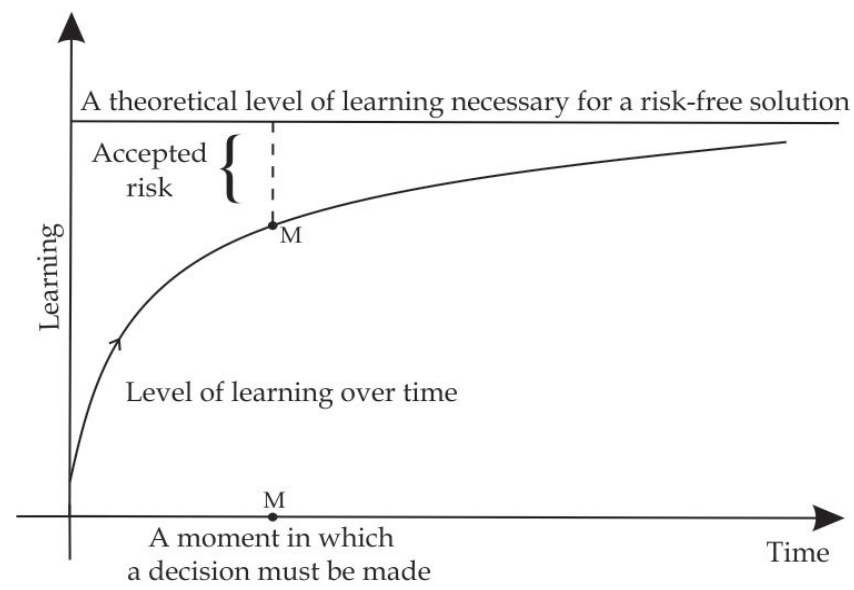

Picture 3: The correlation between indeterminacy and the knowledge about a process when making a decision

It is evident that a business model is of great use when identifying what is essential and what is not to an organization, i.e. what its target consumer group is, or what the suggested value (quality) is. By identifying the possible risks to the success of a system, attention is directed towards the assessment of an organization, and not primarily to increasing the size of the system, which is important for the sustainability of its business.

\section{Conclusion}

Considering the intensity and frequency of change in the environment, an organization's business system must be adapted more quickly and more efficiently for the successful survival of its business on the market. In order to be able to accomplish this, an organization should have a clear picture of the future of its competitive situation and reliable innovative processes. What is important is the way in which an organization creates and delivers value to clients and attains profit. The key to a successful business of every organization is the business model on which it is based.

A changeable situation on the market caused by various factors demands much quicker and more intense adjustment and innovation of business systems to ensure the 
survival of an organization. Thus the successfulness of a business model needs to be based on the creation of appropriate relations among all the elements and their harmonization. Each component contains a lot of information on the organization's business model. By changing any element, the entire map of the model is changed and the organization's business model undergoes change which is reflected on the value the organization places on the market.

Bearing in mind the intensity and frequency of change, it is also necessary to create a theoretical framework which could enable the identification and mastering of the process of business model innovation. Taking into account that these are not isolated events but a process that is most likely going to become more and more intense, it needs to be systematized. From the aspect of the quality management's system assessment, the concept of the business model makes it easier to understand business itself in a given organization.

\section{References}

Afuah, A. (2004). Business models: A strategic management approach. Columbus, $\mathrm{OH}$ : McGraw-Hill Higher Education.

Baden-Fuller, Charles; Mary S. Morgan (2010). "Business Models as Models". Long Rang Planning. 43 (2/3): 156-171.

Blank, S. A. (2005). The Four Steps to the Epiphany: SuccessfulStrategies for Products that Win. Second Edition. K \& S Ranch.

Baden-Fuller, C.; Mangematin, V. (2013). „Business models: A challenging agenda“. Strategic Organization, Vol. 11, No. 4, pp. 418-427.

Božolović, S. \& V. Miletić, (2014), IMS - Concept(s) of Successful Leadership Organization, 9th International multidisciplinary Scientific Conference "Eurobrand", december, NGO TQM Center Zrenjanin, е-Зборник радова, стр. 35-44

Cliffe, S.; McGrath, R. G. (2011). „When your business model is introuble“. Harvard Business Review http:/www.crowehorwath.com/folio-pdfhidden/ WhenYourBusiness ModelisinTrouble.pdf (18.07.2018.)

Casadesus-Masanell, R.; Ricart, J. E. (2010). „From strategy to businessmodels and onto tactics“. Long range planning, Vol. 43, No. 2, pp. 195-215.

Chesbrough, H. (2007). „Business model innovation: it's not just abouttechnology anymore“. Strategy \& leadership, Vol. 35, No. 6, pp. 12-17.

Cowan A. (2013). Alex Cowan. from The 30 Minute Business Plan: BusinessModel Canvas Made Easy, 30.07.2018,

Drucker. P, (1994): «The theory of the Business», Harvard Business Review. September - october, p. 95-104

Dwight C. (2015). What Is Business Model Innovation? http://www.ehow. com/ about_7220445_b usiness-model-innovation_html 31.7.2018

Fensel, D. (2001). Ontologies: Silver Bullet for Knowledge Managementand Electronic Commerce. Heidelberg: Springer-Verlag. 
George, G. and Bock AJ. (2012). Models of opportunity: How entrepreneurs design firms to achieve the unexpected. Cambridge University Press,

Geissdoerfer, Martin; Savaget, Paulo; Evans, Steve (2017). "The Process of Innovative Process in Cambridge". Procedia Manufacturing. 8: 262-269.

Lambert, s. C., (2006), A Business Model Research Schema

Linde H., Herr G., Rehklau A. (2006). Innovation Of The Integrated ProductAnd Process Development by WOIS. TRIZ Conference 2006 . Osaka:

Miletić, V., Z. Jovanović, Lj. Jeremić, (2017), Progresive Managament System - a Development and Organization Manager to Succes, Ekonomika Niš, br. 3, str. $35-43$,

Serrat, O., (2012). Business Model Innovation. Knowledge Solutions, January 2012 | 111, Asian Development Bank, 1-8.

Zott, C. R. Amit, \& L.Massa, (2010). 'The Business Model: Theoretical Roots, Recent Developments, and Future Research’, WP-862, IESE, June, - revised September 2010

The MIT Centre for Digital Business, Case Study, Volvo Cars Corporation: Shifting From a B2B to a "B2B+B2C"Business Model, 2011

Teece, D. J. (2010). „Business models, business strategy and innovation“. Long range planning, Vol. 43, No. 2, pp. 172-194.

Unpacking Business Models: 21st Century Solutions for Sourcing Services, (2014), University of Tennessee

Zott, C.; Amit, R.; Massa, L. (2010). „The business model: Theoretical roots, recent developments, and future research“. IESE business school - University of Navarra, pp. 1-43.

https://www.pokreni.se/business-canvas-model/ 